\title{
Post-Millennials Stressors, Ego Resilience, Gratitude, and Life Satisfaction: The Basis for Mental Health Program
}

\author{
Ian Bunyag Arcega ${ }^{*}$, Rogie Orbita Dadivas ${ }^{2}$, Johnny Dogelio Dariagan $^{3}$ \\ ${ }^{1,2,3}$ College of Management, Capiz State University, Roxas City Main Campus, Philippines \\ *Corresponding author.Email: ibarcega@capsu.edu.ph
}

\begin{abstract}
Resilient and grateful individuals experienced a high level of adversity and demonstrated a high level of competence and adaptation. The study aimed to determine the respondents' sources of stress, while knowing the level of ego resiliency, life satisfaction, and gratefulness as a basis for a contextualized mental health program. It used a descriptive-exploratory research design. The researchers utilized an adapted instrument called the Revised University Student's Hassle Scale (RUSHS) to gather the needed data. The respondents of the study were the 278 postmillennials, who are currently enrolled at Capiz State University. The constructs of the study focused on the sources of stress, ego resiliency, gratitude, and life satisfaction of the respondents. The findings revealed that stresses experienced were the academic and personal related. Their ego resilience was moderately high, but it was affected by various factors that they could not handle, which directly affect their life satisfaction and their being grateful and ungrateful of the things happening in the world and their personal life.
\end{abstract}

Keywords: Bayani Hub, Ego Resiliency, Gratitude, Life Satisfaction, Mental Health, Post-Millennials, Stressors

\section{INTRODUCTION}

In the past years, psychology has shifted its concentration from treating and preventing mental disorders, which could aid individuals in attaining wellbeing and living a fulfilled and satisfied life. As proposed, well-being goes beyond the absence of illness such as aspiration, enthusiasm, and confidence for life [31]. Positive psychology, an approach concentrating on strengths and virtues, changed its focus of the mental health field from primarily treating health problems (e.g., medical model) to using powers to buffer individuals from mental disorders and obtain well-being [30].

It is indispensable to investigate the relationship between stressors, ego resiliency, gratitude, and life satisfaction. In some human life panorama, we could not control everything, specifically certain things that would happen (e.g. being born into dysfunctional families or poverty, having accidents, encountering natural disasters); however, we could control the response to those events. In this case, resiliency is very essential in coping with hard knocks in life to be able to continue in pursuing life's wants. With this, character strength like gratitude could help attain well-being.

It is worthwhile, therefore, to find out stressors related to resiliency, gratitude, and life satisfaction for people to cope with life's adversities, attain eudaimonia and eventually have a fulfilled, prosperous life. With the challenges our youth today encountered, their mental health is already at risk. There were suicide incidents reported, drug-related cases, and others, which the child was involved. The researchers then looked upon these cases to conceptualize mental health programs, hence this study.

\subsection{Statement of the Problem}

The study explored and examined the sources of stress, ego resiliency, life satisfaction, character strengths, and resiliency of the students as a basis for mental health programs.

Specifically, it sought answers to questions:

1. What are the stresses most often experienced by the post-millennials in terms of significant life events?

2. What is the ego resiliency level of the postmillennials? 
3. What is the life satisfaction level of the postmillennials?

4. Are the stresses experienced by the postmillennials significantly affect their ego resiliency level?

5. Is the ego resiliency level of the students significantly predict their life satisfaction?

6. Are there significant differences in the resiliency level and life satisfaction of the students?

7. Is there an important relationship between life satisfaction and the gratefulness of the postmillennials?

8. How to utilize the findings of the study in developing a contextualized mental health program?

\subsection{Theoretical Framework}

Resiliency Theory, System Theory, System Framework, and the Republic Act No. 11036, otherwise known as the Mental Health Law of 2018 were the theories and framework, which the study was anchored.

\section{The Framework of the Study}

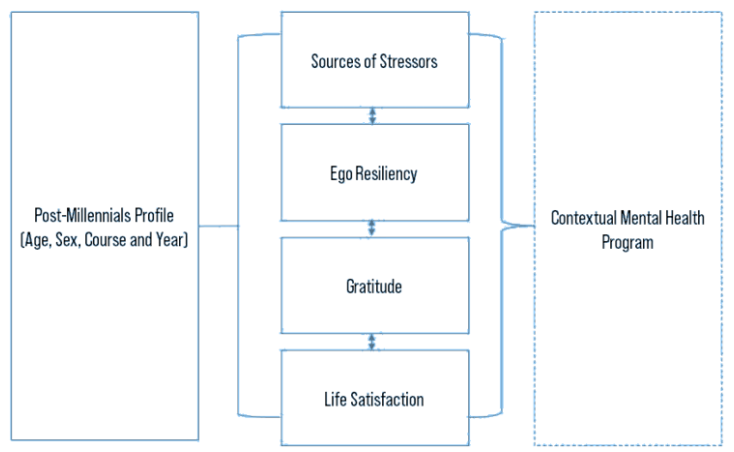

Figure 1. Showing the framework of the study

\section{METHOD}

This is a descriptive research utilizing the quantitative and qualitative methods in gathering the data to explore and examine the respondents' sources of stress, life satisfaction, gratitude, and ego resiliency as a basis for the mental health program. The researchers did an in-depth random interview with the postmillennials. An adapted and revised research instrument was utilized in gathering the data, for gratitude questions [24]; Ego Resiliency [4]; The Revised University Student's Hassle Scale (RUSHS) [27]; and, The Satisfaction with Life Scale [9]. The researchers used a stratified random sampling for the sample size. For four hundred (400) total population, the sample size was 278 of which 139 were males and 139 were females from the first to fifth-year level, and they belonged to the College of Education, College of Engineering, Architecture, and Technology, and College of Management. Those respondents, who were not born from 1997 to present were not allowed to participate in the study. The reliability coefficient result was 0.902 .

The statistical tools used were mean, ranking, regression analysis, and f-test.

\section{RESULTS AND DISCUSSIONS}

\subsection{Post-Millennials Stresses}

Table 1 discloses the post-millennials' stressors and their severity. The total grand mean was 2.97 with a verbal interpretation of occasionally. It implied that the stressors occurred sometimes, affecting the postmillennials because of their severity. The postmillennials rated the severity of the stressors experienced from 1 to 10 . Furthermore, the results showed the top 10 stressors as: (1) when they make friends; (2) studying the lessons for various classes; (3) school-related expenses; (4) too many things to accomplish; (5) coping with the class assignment deadlines; (6) safety of their personal belongings; (7) organizing time; (8) the pressure to get good grades; (9) traffic; and (10) balancing school and social relationships. This implied that the stressors, which often occur were primarily academic and personalrelated. Hence, when it comes to the severity of the stressors, it happened frequently and occasionally. It was also highlighted that those post-millennials had a hard time balancing academic-related and personal things. Since they had a hard time managing their time, it also stresses them on the social relationships with their friends, family, and partners.

The stresses the post-millennials experienced were comparatively small and unanticipated events disturbing their life [15]. Thereby, these daily stressors were unexpected irritants and frustrations. Although daily stressors are less striking than life's important events, they are already sensed as stressful when people acknowledged them they had happened [15][17]. Whereby, research indicates that daily stressors are negatively related to an individual's overall well-being.

Thus, individuals reported physical and psychological discomfort on days when they experienced stressors compared to those without stress [2]. Other studies found a better mood on an individual with stress-free days that followed a day with stressors than those without any stressors [41]. 
Table 1. Post-millennials stressors often occurred and their severity

\begin{tabular}{|c|c|c|c|c|}
\hline Statements & S.D. & Mean & $\begin{array}{c}\text { Verbal } \\
\text { Interpretation }\end{array}$ & Rank \\
\hline 1. Fear of losing valuables & 1.04 & 2.84 & Occasionally & 36.5 \\
\hline 2. Traffic & 1.29 & 3.35 & Occasionally & 9 \\
\hline 3. People making fun of their religion & 1.27 & 2.31 & Occasionally & 54 \\
\hline 4. Making friends & .92 & 4.15 & Frequently & 1 \\
\hline 5. Weight concerns & 1.12 & 3.15 & Occasionally & 18.5 \\
\hline 6. Balancing school and social relationships & 1.24 & 3.33 & Occasionally & 10.5 \\
\hline 7. Problem on the job and school & 1.26 & 2.81 & Occasionally & 39 \\
\hline 8. Demanding parents & 1.29 & 3.00 & Occasionally & 28 \\
\hline 9. Studying for class & 1.00 & 3.88 & Frequently & 2 \\
\hline $\begin{array}{l}\text { 10. Being treated differently because of race, ethnicity, } \\
\text { and sexuality }\end{array}$ & 1.18 & 2.21 & Rarely & 58 \\
\hline 11. Not enough money for emergencies & 1.30 & 3.24 & Occasionally & 15 \\
\hline 12. Concentrating on school-work & 1.18 & 3.31 & Occasionally & 12 \\
\hline 13. Safety of personal belongings & 1.05 & 3.42 & Frequently & 6 \\
\hline 14. Parking & 1.46 & 2.75 & Occasionally & 45 \\
\hline 15. Concerns about meeting high standards & .92 & 2.98 & Occasionally & 29 \\
\hline 16. Not enough money for entertainment & 1.12 & 3.23 & Occasionally & 16.5 \\
\hline $\begin{array}{l}\text { 17. People assume I am rich/poor because of my } \\
\text { race/ethnicity/class status }\end{array}$ & 1.10 & 2.76 & Occasionally & 43 \\
\hline 18. Financial security & .85 & 2.84 & Occasionally & 36.5 \\
\hline 19. Driving around city/municipality & 1.13 & 2.28 & Occasionally & 55 \\
\hline 20. Physical appearance & 1.03 & 2.91 & Occasionally & 31 \\
\hline 21. Not enough money for housing & 1.16 & 2.86 & Occasionally & 33.5 \\
\hline 22. The pressure to get good grades & 1.12 & 3.41 & Frequently & 7.5 \\
\hline 23. Not enough time for family & 1.11 & 2.85 & Occasionally & 35 \\
\hline 24. Owing money & 1.19 & 2.83 & Occasionally & 38 \\
\hline 25. School expenses & 1.13 & 3.61 & Frequently & 3 \\
\hline 26. Getting into shape & .91 & 2.56 & Rarely & 48 \\
\hline $\begin{array}{l}\text { 27. People unable to relate to a different personality, } \\
\text { color, and sexuality }\end{array}$ & 1.18 & 2.55 & Rarely & 49.5 \\
\hline 28. Too many responsibilities & 1.03 & 3.12 & Occasionally & 21 \\
\hline 29. Feeling neglected by my race, status, and sexuality & 1.00 & 2.50 & Rarely & 51 \\
\hline $\begin{array}{l}\text { 30. Trouble relaxing (hard time coping with stress, } \\
\text { anxiety, and depression). }\end{array}$ & .98 & 3.02 & Occasionally & 27 \\
\hline 31. Personal Safety & 1.21 & 3.08 & Occasionally & 23.5 \\
\hline 32. Not having close friends & 1.35 & 2.23 & Rarely & 56.5 \\
\hline 33. Feeling discriminated & .96 & 2.37 & Rarely & 53 \\
\hline 34. Life Satisfaction & .94 & 3.06 & Occasionally & 25.5 \\
\hline 35. Being treated differently due to gender & 1.20 & 2.23 & Rarely & 56.5 \\
\hline 36. Not enough personal energy & 1.16 & 3.13 & Occasionally & 20 \\
\hline 37. Introducing myself at school & 1.14 & 3.23 & Occasionally & 16.5 \\
\hline 38. Not taken seriously because of my gender & 1.34 & 2.64 & Occasionally & 47 \\
\hline 39. School learning material is difficult & .94 & 3.27 & Occasionally & 13 \\
\hline 40. Organizing time & 1.06 & 3.41 & Frequently & 7.5 \\
\hline 41. Not enough money for clothing & 1.05 & 2.86 & Occasionally & 33.5 \\
\hline 42. Going out with friends & 1.12 & 3.10 & Occasionally & 22 \\
\hline 43. Denied opportunities because of gender & 1.04 & 2.45 & Rarely & 52 \\
\hline 44. Being lonely & 1.16 & 2.76 & Occasionally & 43 \\
\hline 45. Dependence on parents & 1.12 & 3.25 & Occasionally & 14 \\
\hline 46. School schedule & 1.16 & 3.15 & Occasionally & 18.5 \\
\hline $\begin{array}{l}\text { 47. Perceptions of others have been based on cultural } \\
\text { stereotypes }\end{array}$ & 1.12 & 2.80 & Occasionally & 40.5 \\
\hline 48. Communication problems with friends & 1.05 & 2.76 & Occasionally & 43 \\
\hline 49. Parental expectations & 1.12 & 2.89 & Occasionally & 32 \\
\hline $\begin{array}{l}\text { 50. Someone saying, "Here, let me do that," thinking I } \\
\text { cannot do it because of my gender disabilities }\end{array}$ & 1.26 & 2.69 & Occasionally & 46 \\
\hline 51. Class assignment deadlines & 1.19 & 3.43 & Frequently & 5 \\
\hline
\end{tabular}




\begin{tabular}{lcccc}
\hline 52. People making gender jokes & 1.24 & 3.06 & Occasionally & 25.5 \\
53. Too many things to do & 1.21 & 3.54 & Frequently & 4 \\
54. Driving or commuting to school & 1.32 & 3.33 & Occasionally & 10.5 \\
55. Close mindedness toward my religious beliefs & 1.19 & 2.80 & Occasionally & 40.5 \\
56. Locking up personal belongings & 1.10 & 2.94 & Occasionally & 30 \\
57. Feeling unaccepted because of my religion & 1.42 & 2.55 & Occasionally & 49.5 \\
58. Health condition & 1.10 & 3.08 & Occasionally & 23.5 \\
$\quad$ Grand Mean & & $\mathbf{2 . 9 7}$ & Occasionally \\
\hline
\end{tabular}

Note: 4.21-5.0=Always Occurred; 3.41-4.20=Frequently; 2.61-3.40=Occasionally; 1.81-2.60=Rarely; 1.0$1.80=$ Did not occur

Table 2. Post-millennial ego resiliency

\begin{tabular}{|c|c|c|c|}
\hline Statements & S.D. & Mean & $\begin{array}{c}\text { Verbal } \\
\text { Interpretation } \\
\end{array}$ \\
\hline I am generous with my friends. & .71584 & 2.98 & Moderately High \\
\hline I quickly get over it and recover from being anxious. & .77835 & 2.61 & Moderately High \\
\hline I tend to buy things on impulse. & .82830 & 2.38 & Low \\
\hline I enjoy dealing with new and unusual situations. & .92735 & 2.66 & Moderately High \\
\hline I usually succeed in making a favorable impression on people. & .71609 & 2.61 & Moderately High \\
\hline When I get bored, I like to stir up some excitement. & .86457 & 2.78 & Moderately High \\
\hline I enjoy trying new foods I have never tasted before. & .86580 & 2.81 & Moderately High \\
\hline I am regarded as a very energetic person. & .78507 & 2.77 & Moderately High \\
\hline I often get involved in things I later wish I could get out. & .83299 & 2.56 & Low \\
\hline I like to take different paths to familiar places. & .78606 & 2.65 & Moderately High \\
\hline I am more curious than most people. & .82636 & 2.65 & Moderately High \\
\hline $\begin{array}{l}\text { Sometimes I instead enjoy going against the rules and doing things } \\
\text { I am not supped to do. }\end{array}$ & .92736 & 2.70 & Moderately High \\
\hline Most of the people I meet are likable. & .83215 & 2.70 & Moderately High \\
\hline I usually think carefully about something before acting. & .68931 & 3.21 & Moderately High \\
\hline I finish one activity or project before starting another. & .78469 & 2.92 & Moderately High \\
\hline I like to do new and different things. & .81559 & 3.07 & Moderately High \\
\hline My daily life is full of things that keep me interested. & .87763 & 2.74 & Moderately High \\
\hline At times I have worn myself out by undertaking too much. & .66884 & 2.57 & Low \\
\hline $\begin{array}{l}\text { I would be willing to describe myself as a pretty "strong } \\
\text { personality." }\end{array}$ & .94621 & 3.00 & Moderately High \\
\hline I get over my anger at someone reasonably quickly. & .74699 & 2.96 & Moderately High \\
\hline Grand Mean & & 2.77 & $\begin{array}{l}\text { Moderately } \\
\text { High }\end{array}$ \\
\hline
\end{tabular}

Note: 4.21-5.0=Very High; 3.41-4.20=High; 2.61-3.40=Moderately high; 1.81-2.60=Low; 1.0-1.80=Very Low 


\subsection{Post Millennials Ego Resiliency}

Table 2 reveals the post-millennials' level of ego resiliency. The results show a grand mean of 2.97 with a verbal interpretation of moderately high. There were some findings that ego resiliency was interpreted as low as post-millennials tend to become impulsive buyers; they often involved in various things and later had a hard time getting out from the situation or circumstances they dealt with, and became worn out of the undertakings they do. It implied that the ego resiliency of the post-millennials was dependent on their adaptability to the changing demands of the internal and external environment.

The ego resiliency concept encompasses traits emphasizing flexibility and resiliency toward the constantly varied situations and the general personality resourcefulness. Moreover, it is a proper behavior since ego resilient individuals are intelligent, resourceful, and adaptive to nerve-wracking conjunctures [15]. By that, ego resiliency is associated with a flexible invocation of the available repertoire of problem-solving strategies, promoting socialization.

When individuals experience risk in life, they may feel that the experience is a crisis. Thus, there is also an opportunity [6]. Individuals who encounter troubles may acquire more competence and knowledge because of the incidents, develop maladaptive strategies or regress to lower levels of competence than before meeting the crisis.

As Shakespeare wrote in As you Like It, "Sweet are the uses of crisis/risks" [15]. Adversity may weaken or strengthen the individual, depending on how they "use" it. Encountering hardship could be very painful. It may strike the individual to the point that they may not continue with a healthy life. On the other hand, if the individual can overcome adversity, that would serve as an opportunity or a challenge allowing them to grow stronger and gain more competence (i.e., be resilient).

\subsection{Level of Life Satisfaction}

Table 3 discloses the post-millennials' level of satisfaction. The results show a grand mean of 4.93 with a verbal interpretation of somewhat satisfied. It was revealed that among five (5) questions, there were some questions, which the post-millennials were neither satisfied nor dissatisfied, such as "they have forgotten the important things they want in life" and "if they could live their life again, they will change almost nothing." It implied that their present life had no complete satisfaction because of the challenges and hardships they experienced. Hence, they also devalue the importance of the life they want, and if given a chance, that will change something in the present life they have.
Life satisfaction varies among post-millennials. Those who were motivated for intellectual activities reported higher levels of life satisfaction than those who did not [8]. A sense of identity was related to overall life satisfaction [16]. Life satisfaction was associated with happiness. Delighted people are more satisfied with life than unhappy people [12]. People's levels of life satisfaction were closely related to their overall physical and mental health [1].

Research also highlighted that life satisfaction is associated with social relationships: the more satisfying the social connection, the more incredible life satisfaction is. Nevertheless, in the present study, the results are not the same as the previous study since social relationship is one of the major stressors of the post-millennials.

Table 3. Level of life satisfaction of post-millennials

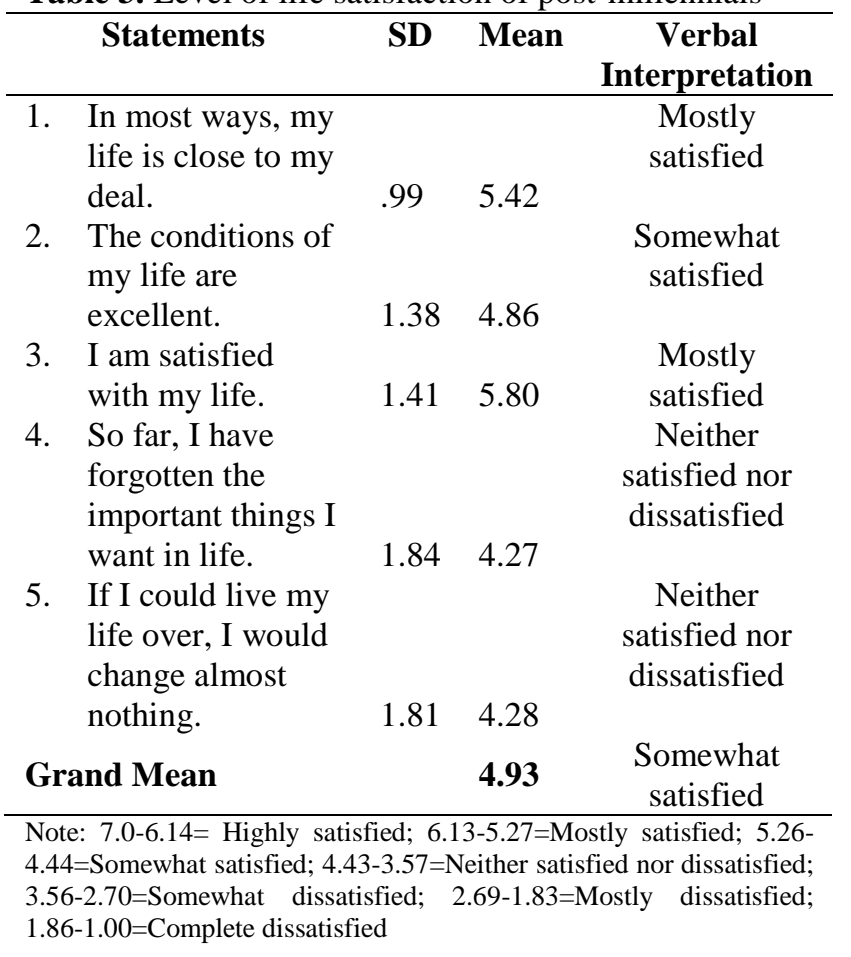

\subsection{Gratefulness of Post-Millennials}

Table 4 shows how grateful are the post-millennials. The results reveal a grand mean of 4.44 with a verbal interpretation of somewhat appreciative. However, there were some statements, which the post-millennials were neither grateful nor ungrateful on the present happenings of the world. It implied that postmillennials were not happy and thankful for the uncontrollable things happening in the world and their personal life.

Research suggests that gratitude is beneficial to one's personal well-being and society. Gratitude motivates people's prosocial behaviors toward others [26]. Gratitude was positively correlated with 
spirituality/religiousness and negatively correlated with materialism. It causes happiness and reduces the harmful effects of materialistic pursuits leading to life's dissatisfaction (i.e. feelings evoked by receiving help from others) among university students in Japan and Thailand. It was found out that students from these two countries reported positive feelings (e.g. joy, warmth, happiness, and thankfulness) and negative feelings, indebtedness (e.g. shame, regret about causing a problem, and uneasiness indebtedness) after receiving a favor. Both positive feelings and feelings of indebtedness were components of gratitude. Positive feelings were associated with facial and verbal expressions of gratitude, giving back (e.g. giving money or goods), and enhanced prosocial behaviors. Feelings of indebtedness were associated with the cost to the benefactors and giving back to the benefactors [25].

Table 4. Level of gratefulness of post-millennials

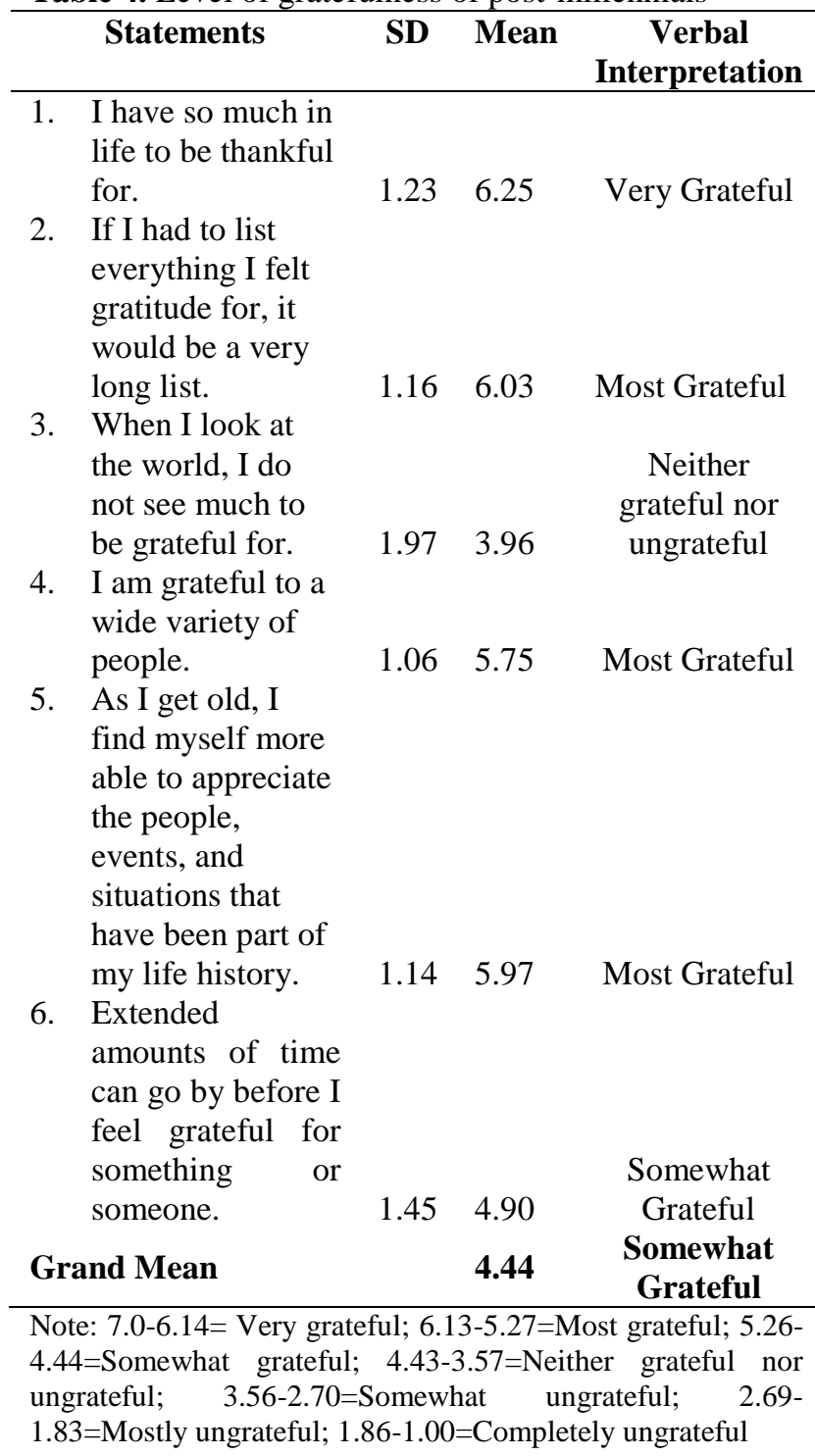

\subsection{Stresses significantly affect the ego resiliency of the post-millennials}

Table 5 shows that stresses the post-millennials experiences significantly affect (r-value-.297; sig.value.000) their ego resiliency. It implied that problems they experienced, whether academically or personally, directly impact their ego resiliency in coping with the situation or crisis and adversity. Individuals under highstress levels sought help and support to decrease their stress levels to increase their resiliency and satisfaction.

Resilience is a positive adaptation by individuals despite the experience of significant adversity [18]. A diagnostic model of resilience was proposed. The model utilized two criteria in identifying resilient individuals: (1) risk/adversity level the individuals experienced; and (2) individuals' competence/adaptation level. Those who experienced a low level of risk/adversity and demonstrated a low level of competence/adaptation were considered a highly vulnerable group, while those who experienced a high level of risk/adversity and exhibited a low level of competence/adaptation were considered a maladaptive group. Moreover, those who experienced a low level of risk/adversity and demonstrated a high level of adaptation were considered competent unchanged. Resilient individuals experienced a high level of risk/adversity and demonstrated a high level of competence/adaptation [22].

Table 5. Stressors significantly affect the postmillennial ego resiliency level

\begin{tabular}{lcr}
\hline & Pearson-r & Sig. Value \\
\hline Stress Experienced & .287 & .000 \\
Ego Resiliency & & \\
\hline $\mathrm{p}<.05 \%$ significant & &
\end{tabular}

\subsection{Post Millennials Ego Resiliency Predict their Life Satisfaction}

Table 6 discloses that the post-millennials' ego resiliency did not significantly predict (f-value-.70; sig.value-.792) their life satisfaction. It implied that the post-millennials' level of ego resiliency varies from each other, how they handle and cope with it that directly predict their life satisfaction.

Various research results postulate that the relationship between life satisfaction and resiliency is not consistent. Resiliency was correlated to life satisfaction [14]. Resiliency was not only positively related to life satisfaction, but also significantly predicted life satisfaction [16]. There was no relationship between resiliency and life satisfaction. That is, resilient individuals' levels of life satisfaction did not relate to non-resilient individuals [15][7]. 
Table 6. The Ego-Resiliency level significantly predicts life satisfaction

\begin{tabular}{lcl}
\hline & F-value & Sig. Value \\
\hline Ego resiliency & .070 & .792 \\
Life satisfaction & & \\
\hline p $>05 \%$ not significant & &
\end{tabular}

\subsection{Significant Difference in the Ego Resiliency and Life Satisfaction of the Post Millennials}

Table 7 shows the result of the significant difference in the ego resiliency and life satisfaction of the postmillennials (f-value of 6.280 with a substantial value of .000). It implied that individuals' ego resiliency and life satisfaction differed depending on their competency, experience, and background.

Resiliency used to be sensed as some remarkable attributes within only some individuals [23]. Factors contributory to resilience (e.g. individual characteristics, life satisfaction, and supports from the environment) seem to be universal, crossing ethnicities, cultures, and socioeconomic strata [40]. The effectiveness of protective factors, varies with the individual's developmental level and forms of risk [29]. People can be resilient and satisfied at some points in their lifetime, coping with some types of adversity, but not at others [15][18][19].

Table 7. The significant difference in the Ego Resiliency and Life Satisfaction of the post-millennials.

\begin{tabular}{lll}
\hline & F-value & Sig. Value \\
\hline Ego resiliency & 6.280 & .000 \\
\hline $\mathrm{p}<.05 \%$ significant &
\end{tabular}

\subsection{Significant Relationships between Life Satisfaction and the Level of Gratitude of Post Millennials}

Table 8 shows significant relationships (r-value.429; sig.value-.000) between life satisfaction and the level of gratitude of post-millennials. It implied that post-millennials' life satisfaction directly correlated to their perspectives and beliefs on gratitude. Being grateful for small and big things poses unique life satisfaction. Compared to less grateful people, grateful people experience more intense feelings of gratitude when experiencing a positive event and experience feelings of gratitude more frequently each day. Also, grateful people feel gratitude for more aspects of their lives (e.g. family, religion, work, society) in general and for more people in response to the same positive event than do less grateful people.

Gratitude has an amazing power in uplifting and focusing people on what is still whole and enjoyable in life, even at the worst of times [28]. Gratitude is an emotional state and attitude in life serving as a source of human strength in enhancing one's personal and relational well-being [15]. Gratitude is one of the characteristics (e.g. integrity, optimism) shared by adolescents with a sense of purpose, one of the protective factors for resiliency; thus, gratitude may also be related to resiliency [5]. It seems reasonable then to suggest that gratitude may help people cope with adversities, to be resilient.

Table 8. Significant relationships between life satisfaction and the level of gratitude of post-millennials

\begin{tabular}{lcc}
\hline & Pearson-r & Sig-Value \\
\hline Life satisfaction & .429 & .000 \\
Gratitude & &
\end{tabular}

Gratitude

$\mathrm{p}<.05 \%$ significant

\section{CONCLUSIONS}

The research findings in this paper are a springboard in providing inclusive and equitable mental health services for the post-millennials. Stresses, ego resiliency, life satisfaction, and gratitude are the facets of diverse and empowered individuals. It would be only a criterion for a broader scope of prevention and intervention activities.

This research was carried before the pandemic and offers recommendations for achieving a new postmillennial with resiliency and having a grateful and satisfying life. However, other researchers may uncover other areas to help post-millennials achieve good health and well-being despite life's volatility, uncertainty, complexity, and ambiguity.

\section{Proposed Mental Health Program}

Based on the present findings of the study, it is imperative to develop a contextualized mental health program that is school-based. The proposed program would anchor on the concept of inclusiveness and equity. The program would be called Project Bagani (a Filipino term that means warrior). Why Bagani? The researchers want to prove that post-millennials are born warriors, strong, resilient, grateful in all the circumstances they encounter. Hence, it would also be a benchmark project for other State Universities and Colleges (SUCs) in the Region to consider. The project will focus on the inclusiveness and equity of the delivery of various activities intended for the postmillennials. Below is the continuum framework of Project Bagani.

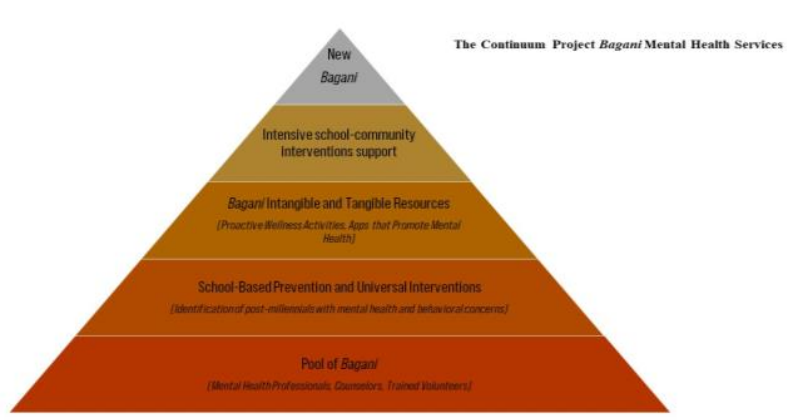


Figure 2. The continuum framework of Project Bagani Mental Health Services.

The Pool of Bagani. This pool of trained volunteers (faculty, parents, staff, students) and mental health professionals are the prime movers of mental health services. They will be trained in handling cases, identification of post-millennials with mental health and behavioral concerns.

School-Based Prevention and Universal Interventions. After the volunteers and professionals identify cases and mental and behavioral concerns, they will process and develop a prevention and intervention plan depending on the matter handled. Researchers will do a series of mental health activities.

Bagani Intangibles and Tangibles Resources. This project will utilize and prepare apps that promote mental health and proactive wellness activities that directly employ the handled cases.

Intensive school-community interventions support. The school and community will work hand in hand in making proactive, inclusive, and equitable mental health interventions.

\section{AUTHORS' CONTRIBUTIONS}

The researchers contributed equally to finish the present study. The impact of this research is the inclusion and approval of the mental health programs in Capiz State University and utilization of the results to the improvement of health services in various Local Government Units in the province of Capiz.

\section{ACKNOWLEDGMENTS}

The researchers extend their gratefulness to the Capiz State University Administration, Faculty, and Students, who gave time and effort to answer the instruments and allow the researchers to conduct a random interview.

\section{REFERENCES}

[1] Abdel-Khalek, A. M., \& Naceur, F. (2007). Religiosity and its association with positive and negative emotions among college students from Algeria. Mental Health, Religion \& Culture, 10(2), 159-170.

[2] Almeida, D. M. (2005). Resilience and vulnerability to daily stressors assessed via diary methods. Current Directions in Psychological Science, 14(2), 64-68.
[3] Benard, N. (n. d). Sharp-Light (Eds), Resiliency in action: Practical ideas for overcoming risks and building strengths in youth, family, and communities (pp. 15-23). CA: Resiliency In Action, Inc.

[4] Block, J. \& Kremen, A. M. (1996). IQ and egoresiliency: Conceptual and empirical connections and separateness. Journal of Personality and Social Psychology, 70(2), 349-361.

[5] Bronk, K. C. (2005). Portraits of Purpose: A study examining the ways a sense of purpose contributes to positive youth development (Doctoral dissertation, Standford University, 2005). Dissertation Abstracts International, 66(8-A), 2839.

[6] Brown, J. H., D’emidio-Caston, M. \& Benard, B. (2001). Resilience education. CA: Corwin Press, Inc.

[7] Cafasso, L. L. (1998). Subjective well-being of inner-city resilient and non-resilient young adolescents (Doctoral dissertation, Loyola University, 1998). Dissertation Abstracts International, 58(12-B), 6840.

[8] Coutinho, S. A. \& Woolery, L. M. (2004). The need for cognition and life satisfaction among college students. College Student Journal, 38 (2), 203

[9] Diener, E., Emmons, R. A., Larsen, R. J. \& Griffin, S. (1985). The Satisfaction with Life Scale. Journal of Personality Assessment, 49, 71-75.

[10] Diener, E. \& Diener, M. (1995). Cross-cultural correlates of life satisfaction and self-esteem. Journal of Personality and Social Psychology, 68(4), 653-663.

[11] Diener, E., Emmons, R. A., Larsen, R. J. \& Griffin, S. (1985). The Satisfaction with Life Scale. Journal of Personality Assessment, 49, 71-75.

[12] Diener, E. \& Seligman, M. E. P. (2002). They very happy couple. Psychological Science, 13, 80-83.

[13] Fredrickson, B. L. (2001). The role of positive emotions in positive psychology: The broaden-andbuild theory of positive emotions. American Psychologist, 56(3), 218-226.

[14] Fredrickson, B. L., Tugade, M. M., Waugh, C. E. \& Larkin, G. R. (2003). What good are positive emotions in crisis? A prospective study of resilience and emotions following the terrorist attacks on the United States on September 11th, 2001. Journal of Personality and Social Psychology, 84(2), 365-376. 
[15] Hsiu-feng, C. (2008). Resiliency and Character Strengths among College Students. ProQuest Information and Learning Company. United States

[16] Huffstetler, B. C. (2006). Sense of identity and life satisfaction in college students (Doctoral dissertation, The University of Tennessee, 2006). Dissertation Abstracts International, 67(9-B), 5407.

[17] King, L. (2000). The role of resiliency, interpersonal relationship restoration, and quality of life for persons in the process of divorce (Doctoral dissertation, Northern Illinois University, 2000). Dissertation Abstracts International, 61(9A), 3474 .

[18] Lazarus, R. S. (1999). Stress and emotion: A new synthesis. New York: Springer Publishing Company.

[19] Luthar, S. S., Cicchetti, D. \& Becker, B. (2000). The construct of resilience: A critical evaluation and guidelines for future work. Child Development, 71(3), 543-562.

[20] Luthar, S. S. (1991). Vulnerability and resilience: A study of high-risk adolescents. Child Development, 62, 600-616.

[21] Masten, A. S. (2001). Ordinary magic: Resilience processes in development. American Psychologist, 56(3), 227-238.

[22] Masten, A. S. \& Coatsworth, J. D. (1998). The development of competence in favorable and unfavorable environments: Lessons from research on successful children. American Psychologist, 53(2), 205-220.

[23] Masten, A. S. \& Reed, M. J. (2002). Resilience in development. In C. R. Snyder \& S. J. Lopez (Eds), Handbook of positive psychology (pp. 74-88). New York: Oxford University Press.

[24] Masten, A. S. (2001). Ordinary magic: Resilience processes in development. American Psychologist, 56(3), 227-238.

[25] McCullough, M. E., Emmons, R. A. \& Tsang, JoAnn (2002). The grateful disposition: A conceptual and empirical topography. Journal of Personality and Social Psychology, 82(1), 112-127.

[26] McCullough, M. E., Emmons, R. A. \& Tsang, JoAnn (2002). The grateful disposition: A conceptual and empirical topography. Journal of Personality and Social Psychology, 82(1), 112-127.

[27] McCullough, M. E., Kilpatrick, S. D., Emmons, R. A. \& Larson, D. B. (2001). Is gratitude a moral affect? Psychological Bulletin, 127(2), 249-266.
[28] Pett, M. A. \& Johnson, M. J. (2005). Development and evaluation of the psychometric properties of the Revised University Student Hassle Scale (RUSHS). Educational and Psychological Measurement, 65(6), 984-1010.

[29] Ryan, M. J. (2006). How to bounce back. Health, 20(7), 146-147.

[30] Schoon, I. (2006). Risk and resilience: Adaptations in changing times. NY: Cambridge University Press.

[31] Seligman, M. E. P. \& Csikszentmihalyi, M. (2000). Positive psychology: An introduction. American Psychologist, 55(1), 5-14.

[32] Sivanathan, N., Arnold, K. A., Turner, N. \& Barling, J. (2004). Leading well: Transformational leadership and well-being. In P. A. Linley \& S. Joseph (Eds), Positive psychology in practice (pp. 241-255). NJ: John Wiley \& Sons, Inc.

[33] Weiner, B. (1985). An attributional theory of achievement motivation and emotion. Psychological Review, 92(4), 548-573.

[34] Weiner, B. (1986). An attributional theory of motivation and emotion. New York: SpringerVerlag.

[35] Werner, E. E. (1985). Stress and protective factors in children's lives. In A. R. Nicole (Ed), Longitudinal studies in child psychology and psychiatry: Practical lessons from research experience (pp. 335-355). NY: John Wiley \& Sons Ltd.

[36] Werner, E. E. (1986). Resilient offspring of alcoholics: A longitudinal study from birth to age 18. Journal of Studies on Alcohol, 47(1), 34-40.

[37] Werner, E. E. (1989). High-risk children in young adulthood: A longitudinal study from birth to 32 years. American Journal of Orthopsychiatry, 59(1), 72-81.

[38] Werner, E. E. (1995). Resilience in development. Current Directions in Psychological Sciences, 4(3), 81-85. Werner, E. (2007). How children become resilient: Observations and cautions. In $\mathrm{N}$. Henderson, B.

[39] Werner, E. E. \& Smith, R. S. (1977). Kauai's children come of age. Hawaii: The University Press of Hawaii.

[40] Werner, E. E. \& Smith, R. S. (1982). Vulnerable but invincible: A longitudinal study of resilient children and youth. NY: McGraw-Hill. Werner, E. E., \& Smith, R. S. (Eds.) (1992). Overcome the 
odds: High-risk children from birth to adulthood. New York: Cornell University Press.

[42] Werner-Wilson, R. J., Zimmerman, T. S. \& Whalen, D. (2000). Resilient response to battering. Contemporary Family Therapy, 22(2), 161-187.
[43] Willoughby, C., Brown, E. G., King, G. A., Specht, J. \& Smith, L. K. (2003). The resilient self-what helps and what hinders? In G. A. King, E. G. Brown, \& L. K. Smith (Eds), Resilience: Learning from people with disabilities and the turning points in their lives. CT: Praeger. 